\title{
Effect of Additives on Arsenic, Boron and Selenium Leaching from Coal Fly Ash
}

\author{
Sri Hartuti, Farrah Fadhillah Hanum, Akihiro Takeyama and Shinji Kambara * \\ Environmental and Renewable Energy Systems Division, Graduate School of Engineering, Gifu University, \\ 1-1 Yanagido, Gifu 501-1193, Japan; amy_srihartuti@yahoo.co.id (S.H.); farrah_fh@yahoo.co.id (F.F.H.); \\ i3023035@yahoo.co.jp (A.T.) \\ * Correspondence: kambara@gifu-u.ac.jp; Tel.: +81-58-293-2581
}

Academic Editor: M. Thaddeus Ityokumbul

Received: 4 April 2017; Accepted: 7 June 2017; Published: 10 June 2017

\begin{abstract}
The establishment of an inexpensive leaching control method to prevent the leaching of trace elements from fly ash is required for the utilization of large-scale fly ash as an embankment material. This study examined the effects of the additives on suppressing As, B, and Se leaching from coal fly ash using $\mathrm{Ca}(\mathrm{OH})_{2}$, paper sludge ashes (PS Ash 3, PS Ash 4 and PS Ash 5), and filter cake (FC). PS Ash and FC are waste generated in the papermaking and lime industry processes and contain high levels of calcium. The treated fly ash $\mathrm{H}(\mathrm{FAH})$ and the resulting mixtures were subjected to a leaching test as per the Environmental Agency of Japan Notifications No. 13. The results indicate that the leaching concentrations of As, B, and Se could be greatly reduced in FAH with the highest effect given by $\mathrm{Ca}(\mathrm{OH})_{2}$, followed by PS Ash 3 and PS Ash $5 . \mathrm{Ca}(\mathrm{OH})_{2}$ greatly reduced both the leaching concentrations of As, B, and Se by about $91-100 \%$, while PS Ash 3 reduced the As and B leaching concentrations by approximately $89-96 \%$ and $83-92 \%$, respectively; and PS Ash 5 reduced the Se leaching concentration by about $87-96 \%$. FC did not have any impact on As and B leaching, but reduced Se leaching by about $58-78 \%$. A reason for the decrease in leaching concentrations of As, B, and Se may be the precipitation with calcium or the formation of ettringite. The presence of leached $\mathrm{Ca}$ and $\mathrm{Na}$ ions are key factors affecting the decrease of As, B, and Se leaching concentrations from fly ash. The utilization of PS Ash 3 and PS Ash 5 as inexpensive additives is a promising method to control the leaching of As, B, and Se into the environment.
\end{abstract}

Keywords: coal fly ash; leaching; calcium; arsenic; boron; selenium

\section{Introduction}

Coal-based power generation is one of the major sources of environmental pollution due to the discharge of large amounts of fly ash into the environment. After burning in a boiler, as the flue gas cools down, trace elements in coal such as As, B, Cr, Sb, and Se condense on the surface of the fly ash and form new stable compounds [1]. Approximately $41 \%$ of the production of fly ash worldwide is utilized in various applications, such as a substitute material for Portland cement, structural fills (usually for road construction), soil stabilization, as a mineral filler in asphaltic concrete and mine reclamation, and the rest is disposed in landfills [2]. The disposal of fly ash in the environment involves the interaction of fly ash particles with weathering and hydrological processes where rainfall causes trace elements in the fly ash to elute and contaminate the environment. The leaching of As, B, and Se from coal fly ash (CFA) is likely to occur as these elements tend to form hydrophilic oxides that are dissolved as oxyanion forms [3].

The beneficial reuse of fly ash as embankment material in road construction has great potential in minimizing the amount of disposed fly ash [4-6], which will reduce the disposal costs incurred by industry, reduce landfill requirements, minimize damage to natural resources caused by excavating 
earthen materials for construction, obtain added value from fly ash, and ultimately conserve production energy.

Among the trace elements found in coal fly ash, $\mathrm{As}, \mathrm{B}, \mathrm{Cd}, \mathrm{Cr}, \mathrm{Hg}, \mathrm{Pb}$, and Se are of the greatest concern as environmental hazards [7]. This study investigated the behavior of As, B, and Se as these elements have recently become a major problem in soil contamination in Japan. Long-term exposure of arsenic-contaminated materials to water may lead to various diseases such as conjunctivitis, hyperpigmentation, cardiovascular diseases, skin cancer, gangrene, and disturbances in the peripheral vascular and nervous systems [8]. Boron can cause nausea, vomiting, redness of the skin, diarrhea, and difficulty swallowing; also, in animals, acute excessive exposure to B may cause rapid respiration, eye inflammation, swelling of the paws, and may affect male reproductive organs [9]. Similarly, excessive Se intake may yield circulatory problems and loss of hair and fingernails in humans [10]. Due to the increased awareness of the environmental impact of fly ash, the leaching of trace elements including As, B and Se needs to be controlled before fly ash utilization. Additionally, the reuse of fly ash as embankment material needs to meet regulations on soil contamination; in Japan, the permissible limits for As, B and Se are $10 \mu \mathrm{g} / \mathrm{L}, 1 \mathrm{mg} / \mathrm{L}$, and $10 \mu \mathrm{g} / \mathrm{L}$, respectively.

Understanding the factors that control the leaching behavior of trace elements is critical in predicting the potential impacts of fly ash on the environment. Several works have been conducted on the leaching behavior of As, B, and Se from CFA. Jiao et al. [11] studied the leaching characteristics of As in fly ash and they found that the presence of $\mathrm{Ca}$ in fly ash plays an important role in the leaching behavior of As. Iwashita et al. [12] suggested that the leaching of B and Se may involve the trapping of $\mathrm{B}$ and Se species by the ettringite phase, leading to a decrease in leaching under alkaline conditions. Wang et al. [13] investigated the effect of $\mathrm{pH}, \mathrm{S} / \mathrm{L}$ ratio, calcium addition, and leaching time on the leaching behavior of As and Se from two major types of CFAs and found that the leaching of As and Se from CFA generally increased with increases in the S/L ratio and leaching time; also, adsorption/desorption played a major role in As and Se leaching from the CFA. Van der Hoek et al. $[14,15]$ showed that the leaching of As and Se from acidic ashes could be described by sorption of iron oxide, while the leaching from the alkaline ashes appeared to be controlled by sorption in the alkaline calcium-phase. Our previous study investigated the leaching characteristics of As from six CFA samples, and described a decrease in the As leaching rate with an increase in $\mathrm{CaO}$ content in fly ash [16].

Overall, Ca content and the sorption process are known to play important roles in the release of As, $\mathrm{B}$, and Se from CFA. Although there have been extensive studies to explain the effect of calcium on As, $B$, and Se leaching and adsorption in fly ash [11-19], the application of additives (which contain high levels of calcium) to suppress As, B, and Se release has been less well established. Furthermore, the utilization of paper sludge ash and filter cake-which are generated as waste in the papermaking and lime industry processes-as inexpensive additives to suppress As, B, and Se leaching from CFA has never been tested. Therefore, the aim of this study was to examine the effects of inexpensive additives on suppressing As, B, and Se leaching from CFA. For this purpose, an appropriate amount of paper sludge ash and filter cake were added to fly ash, and the resulting mixture was subjected to a leaching test. The $\mathrm{pH}$ of the mixture leachates and the relation of As, $\mathrm{B}$, and Se leaching (with major coexisting ions including $\mathrm{Ca}, \mathrm{Na}, \mathrm{K}$, and $\mathrm{Mg}$ in mixture leachates) are discussed. This new information is expected to help in controlling the release of As, B, and Se into the environment to aid in the development of sustainable fly ash management strategies.

\section{Materials and Methods}

\subsection{Coal Fly Ash and Additives}

A relatively high concentration of trace elements leaching (As $48.66 \mu \mathrm{g} / \mathrm{L}, \mathrm{B} 5.39 \mathrm{mg} / \mathrm{L}$, Se $86.9 \mu \mathrm{g} / \mathrm{L}$, detected using ICP-AES) and low calcium content fly ash sample $(2.05 \%$ of $\mathrm{CaO}$, detected using $\mathrm{X}$-ray fluorescence) named fly ash $\mathrm{H}$ (FAH) was collected from a Japanese coal fired power plant 
(600 MWe) for the leaching test. Paper sludge ash (PS Ash 3, PS Ash 4, and PS Ash 5) and filter cake (FC) (considered as suppressing materials) and pure $\mathrm{Ca}(\mathrm{OH})_{2}$ were used in this experiment as the additives. $\mathrm{Ca}(\mathrm{OH})_{2}$ was applied to compare the effect of calcium addition among pure calcium-material $\left(\mathrm{Ca}(\mathrm{OH})_{2}\right)$ and native calcium-material (PS Ash 3, PS Ash 4, PS Ash 5, and FC). Paper sludge ash is waste generated in the papermaking industry as a by-product of the de-inking and re-pulping of paper, while filter cake comes from the lime industry as a waste from the $\mathrm{CaCO}_{3}$ manufacturing process.

The utilization of paper sludge ash and filter cake was considered due to the relatively high content of calcium they contain. The $\mathrm{CaO}$ content detected using X-ray fluorescence (XRF) in PS Ash was varied, ranging from 18.77 to $46.31 \%$. FC had the highest $\mathrm{CaO}$ content at $59.18 \%$. Table 1 lists the composition of inorganic elements in FAH and additives.

Table 1. Composition of inorganic elements in fly ash and additives.

\begin{tabular}{|c|c|c|c|c|c|c|c|}
\hline \multicolumn{3}{|c|}{ Sample } & FAH (1s) $^{1}$ & PS Ash 3 & PS Ash 4 & PS Ash 5 & FC \\
\hline \multirow{12}{*}{$\begin{array}{c}\text { Ash } \\
\text { Composition }\end{array}$} & $\mathrm{SiO}_{2}$ & \multirow{12}{*}[\%]{} & 59.25 & 31.47 & 44.21 & 42.36 & 23.31 \\
\hline & $\mathrm{Al}_{2} \mathrm{O}_{3}$ & & 25.63 & 12.40 & 22.23 & 19.80 & 13.87 \\
\hline & $\mathrm{TiO}_{2}$ & & 1.99 & 0.38 & 2.56 & 2.11 & 0.06 \\
\hline & $\mathrm{Fe}_{2} \mathrm{O}_{3}$ & & 7.49 & 5.13 & 2.63 & 5.56 & 2.33 \\
\hline & $\mathrm{CaO}$ & & 2.05 & 46.31 & 18.77 & 19.51 & 59.18 \\
\hline & $\mathrm{MgO}$ & & 0.79 & 3.28 & 3.42 & 3.30 & 0.96 \\
\hline & $\mathrm{Na}_{2} \mathrm{O}$ & & 0.60 & 0.24 & 0.95 & 0.41 & 0.03 \\
\hline & $\mathrm{K}_{2} \mathrm{O}$ & & 1.56 & 0.20 & 2.09 & 1.99 & 0.25 \\
\hline & $\mathrm{P}_{2} \mathrm{O}_{5}$ & & 0.18 & 0.18 & 1.75 & 1.54 & 0.00 \\
\hline & $\mathrm{MnO}$ & & - & 0.03 & 0.05 & 0.06 & 0.04 \\
\hline & $\mathrm{V}_{2} \mathrm{O}_{5}$ & & 0.03 & 0.01 & 0.02 & 0.02 & 0.02 \\
\hline & $\mathrm{SO}_{3}$ & & 0.42 & 0.36 & 1.31 & 3.33 & 0.00 \\
\hline \multirow{2}{*}{\multicolumn{2}{|c|}{$\begin{array}{l}\mathrm{pH} \text { of the leachate } \\
\text { Leached Ca Ion }\end{array}$}} & & 10.38 & 13.72 & 12.71 & 12.26 & 7.28 \\
\hline & & {$[\mathrm{mg} / \mathrm{L}]$} & 121 & 1405 & 246.5 & 597 & 15.45 \\
\hline \multirow{3}{*}{$\begin{array}{c}\text { Leaching } \\
\text { Concentration }\end{array}$} & As & {$[\mu \mathrm{g} / \mathrm{L}]$} & 48.66 & & & & \\
\hline & B & {$[\mathrm{mg} / \mathrm{L}]$} & 5.39 & & & & \\
\hline & Se & {$[\mu \mathrm{g} / \mathrm{L}]$} & 86.9 & & & & \\
\hline
\end{tabular}

\subsection{Fly Ash Treatment and Leaching Test}

The additive was added to the FAH sample so as to give a Ca content of $5 \%$ and $10 \%$ (see Appendix A). The mixture was then moved to a bowl and distilled water at $25 \%$ addition ratio of the total mixture was added; the mixture was kneaded for one minute, and then scraped and kneaded for a further two minutes. The mixture was then stored in a sealed plastic bag for seven days, following which the mixture was air-dried and the leaching test was conducted.

The procedure of standard leaching tests for fly ash (Notification No. 13 by the Environmental Agency of Japan) was employed as the protocol for leaching tests in this work. The mixture of FAH-additive of $5 \mathrm{~g}$ was mixed with $50 \mathrm{~mL}$ distilled water, which accounted for a liquid to solid ratio (L/S) of 10, and was shaken for six hours at room temperature with a shaking speed of $200 \mathrm{rpm}$. The solid-liquid sample was separated by filtration using a membrane filter of $0.45 \mu \mathrm{m}$ to obtain the filtrate.

\subsection{Characterization of the Elements in CFA and Additives}

The total concentrations of the major chemical compositions in FAH and additives were determined using a Wavelength Dispersive X-ray Fluorescence Spectrometer (WDXRF S8 TIGER, Bruker AXS, Yokohama, Japan). For XRF analysis of the fly ash and additive samples, a small amount (approximately $500 \mathrm{mg}$ ) was poured onto a polypropylene thin-film that was attached previously to a plastic O-ring sample cup with an outer diameter of $40 \mathrm{~mm}$. The samples were analyzed using XRF, and the chemical compositions of samples were determined.

The identification of calcium compounds in the additives was determined qualitatively using thermogravimetric analysis (TG/DTA6300 SII EXSTAR 6000, Hitachi, Hong Kong, China) and X-ray diffraction (LabX XRD6100, Shimadzu, Kyoto, Japan). For thermogravimetric (TG) analysis, a sample 
of 10-20 mg was heated with a measurement temperature from 30 to $1000{ }^{\circ} \mathrm{C}$ at a heating rate of $10{ }^{\circ} \mathrm{C} / \mathrm{min}$ under a nitrogen atmosphere at a flow rate of $200 \mathrm{~mL} / \mathrm{min}$. For XRD analysis, the sample was irradiated with $\mathrm{Cu} \mathrm{K} \alpha$-radiation between 10 and $80^{\circ}(2 \theta)$ with a counting angle at $0.02^{\circ}$ and slit of $0.3 \mathrm{~mm}$, under a scanning speed of $2^{\circ} / \mathrm{min}$, at an acceleration voltage of $40 \mathrm{kV}$ and current of $30 \mathrm{~mA}$. The diffraction pattern was analyzed with the help of the software module "DDView and Sleve," the phases were viewed and identified by applying the database PDF-2/Release 2013 RDB from the International Center for Diffraction Data (ICDD).

\subsection{Chemical Analyses}

The concentrations of As, B, and Se in the filtrate were carefully analyzed by ICP-AES (ULTIMA2, HORIBA Ltd, Tokyo, Japan). Cations such as $\mathrm{Ca}^{2+}, \mathrm{Na}^{+}, \mathrm{K}^{+}$, and $\mathrm{Mg}^{2+}$ were quantified using ion chromatographs IA-300 (DKK-TOA Corporation, Tokyo, Japan). The final pH of the leachate reflected the interaction of the leaching fluid (distilled water) with the buffering capacity of the FAH-additive mixture. The $\mathrm{pH}$ measurement was carried out by a $\mathrm{pH}$ /ion Meter D-53, HORIBA. After $\mathrm{pH}$ meter calibration at $\mathrm{pH} 4,7$, and 9 using buffer solutions, the $\mathrm{pH}$ measurement of samples was carried out.

\section{Results}

\section{1. $p H$ of the Leachates}

A strong relationship between the $\mathrm{pH}$ of the leachate and $\mathrm{CaO}$ content has been recognized since this mineral elevates $\mathrm{pH}$ in the leachates [20-23]. Figure 1 shows the effect of including additives in the $\mathrm{pH}$ of the leachates, where it increased with the treated amount. However, each additive had a different way of elevating $\mathrm{pH}$ that was related to their properties. Of the four additives discussed (after FAH-Ca(OH) 2 mixture leachates), the FAH-PS Ash 3 mixture leachates showed the highest final pH over FAH-PS Ash 5, FAH-PS Ash 4 and FAH-FC mixture leachates for both 5\% and 10\% Ca content samples, as shown in Figure 1. This indicated that the relatively higher CaO content of PS Ash 3 added into fly ash tended to increase the $\mathrm{pH}$ of the mixtures leachates. This was consistent with the previous study in Reference [24], where the release of $\mathrm{Ca}$ from $\mathrm{CaO}$ minerals yielded $\mathrm{Ca}(\mathrm{OH})_{2}$ in aqueous solutions, which is an oxide mineral that significantly contributes to alkalinity. Conversely, FC, which contained the highest $\mathrm{CaO}$ content, did not appear to have any impact on elevating the $\mathrm{pH}$ of the mixture leachates.

To probe the effects of FC addition into FAH, the leaching amount of calcium ions in the FAH-FC mixture leachates was examined (Figure 2). As predicted, the amount of Ca ions leached in the FAH-FC mixture leachates was lower than that of other additives. This result indicates that the low amount of leached $\mathrm{Ca}$ ion in the FC mixture leachates was not enough to elevate the $\mathrm{pH}$ of the leachates. This is relevant with the previous observation in Reference [12], that $\mathrm{pH}$ tended to rise when the Ca leaching amount was larger, where the main species of $\mathrm{Ca}$ such as $\mathrm{CaO}$ elevated the $\mathrm{pH}$ in the leachate. Overall, it could be concluded that an increase of $\mathrm{CaO}$ content in the additives caused an increase in the leachates $\mathrm{pH}$, and that the leached $\mathrm{Ca}$ ions contributed to elevate the leachates $\mathrm{pH}$.

Based on the above discussion, it is clear that the leached $\mathrm{Ca}$ ions in the mixture leachates seemingly play an important role in contributing to the alkalinity of the mixture, especially $\mathrm{Ca}(\mathrm{OH})_{2}$, which possessed high solubility during the leaching test given that $\mathrm{Ca}(\mathrm{OH})_{2}$ is composed of completely water-soluble Ca. As the amount of leached Ca ions yielded was varied due to the diverse solubilities of different calcium compounds in the additives, it was important to identify the types of calcium compounds included in the PS Ash 3, PS Ash 4, PS Ash 5, and FC to better understand the effect of the additives on the $\mathrm{pH}$ of the leachates. To clarify such a hypothesis, TG and XRD analyses were carried out. The results are shown in Figures 3 and 4.

TG was performed on $\mathrm{Ca}(\mathrm{OH})_{2}$ and $\mathrm{CaCO}_{3}$ of $99.9 \%$ purity to confirm that the two weight losses in the TG curve of additives were due to the thermal decomposition of $\mathrm{Ca}(\mathrm{OH})_{2}$ and $\mathrm{CaCO}_{3}$. Figure 3 compares the TG curves of each calcium compound and the additives. The TG analysis of $\mathrm{Ca}(\mathrm{OH})_{2}$, 
$\mathrm{CaCO}_{3}$, and additives was conducted under a nitrogen atmosphere based on the methods decribed in References $[25,26]$. Based on previous study, $\mathrm{Ca}(\mathrm{OH})_{2}$ was thermally decomposed at $330-460{ }^{\circ} \mathrm{C}$ into $\mathrm{CaO}$ [26], and $\mathrm{CaCO}_{3}$ was thermally decomposed into $\mathrm{CaO}$ at around $700{ }^{\circ} \mathrm{C}$ [27]. As seen in Figure 3, the weight losses in PS Ash 3 at around $390{ }^{\circ} \mathrm{C}$ and $600{ }^{\circ} \mathrm{C}$ corresponded to the thermal decompositions of $\mathrm{Ca}(\mathrm{OH})_{2}$, and $\mathrm{CaCO}_{3}$. The weight losses in PS Ash 4 (around $600{ }^{\circ} \mathrm{C}$ ), PS Ash 5 (around $590^{\circ} \mathrm{C}$ ), and $\mathrm{FC}$ (around $700{ }^{\circ} \mathrm{C}$ ) corresponded to the thermal decomposition of $\mathrm{CaCO}_{3}$. From these results, it was found that the $\mathrm{Ca}(\mathrm{OH})_{2}$ and $\mathrm{CaCO}_{3}$ in additives could be detected by TG. Since the decomposition temperature of $\mathrm{CaO}$ is above $1000{ }^{\circ} \mathrm{C}$ [25] and cannot be detected by TG, the analysis of calcium compounds in the additives was performed using the XRD method.

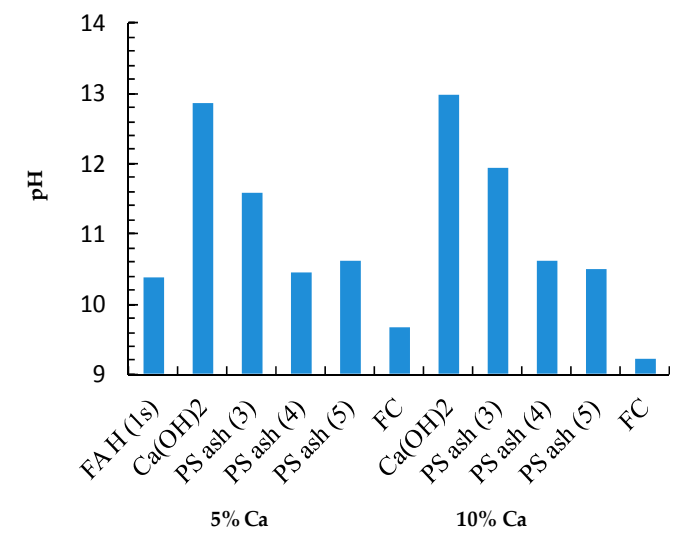

Figure 1. Leachate $\mathrm{pH}$ values from fly ash $\mathrm{H}$ alone and fly ash $\mathrm{H}$ under five kinds of additives for $5 \%$ and $10 \%$ Ca content samples.

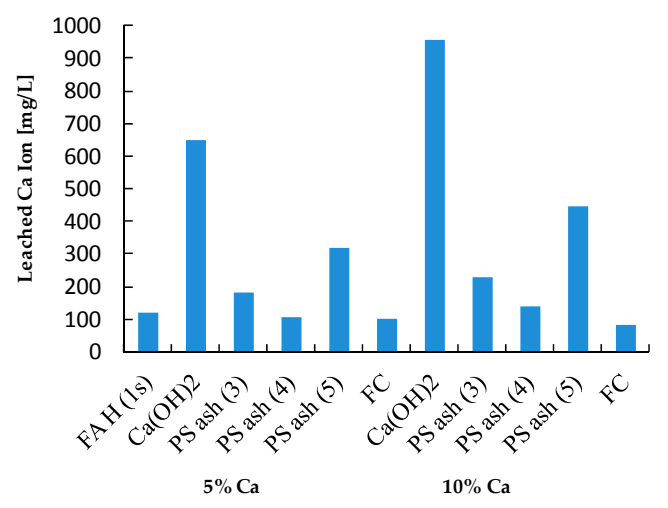

Figure 2. Ca ions leached from fly ash $\mathrm{H}$ alone and fly ash $\mathrm{H}$ under five kinds of additives for $5 \%$ and $10 \%$ Ca content samples.

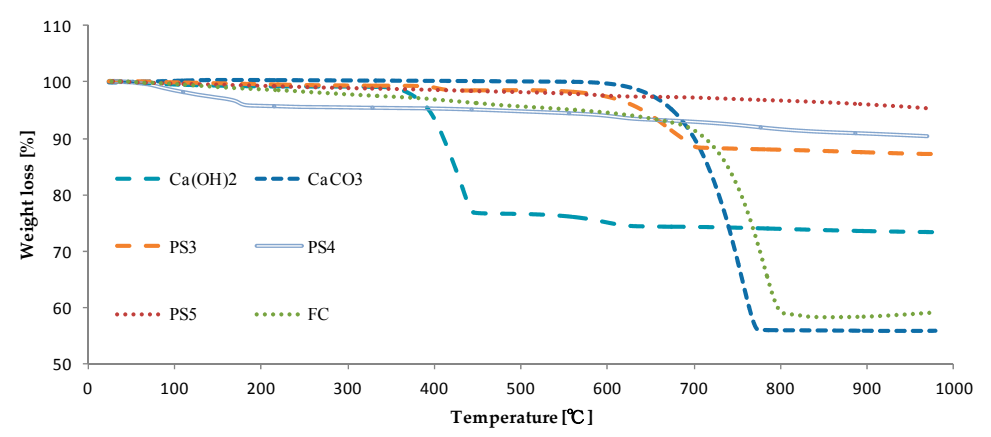

Figure 3. Thermogravimetric curves showing the thermal decomposition of $\mathrm{Ca}(\mathrm{OH})_{2}, \mathrm{CaCO}_{3}$, and additives in a $\mathrm{N}_{2}$ atmosphere. 


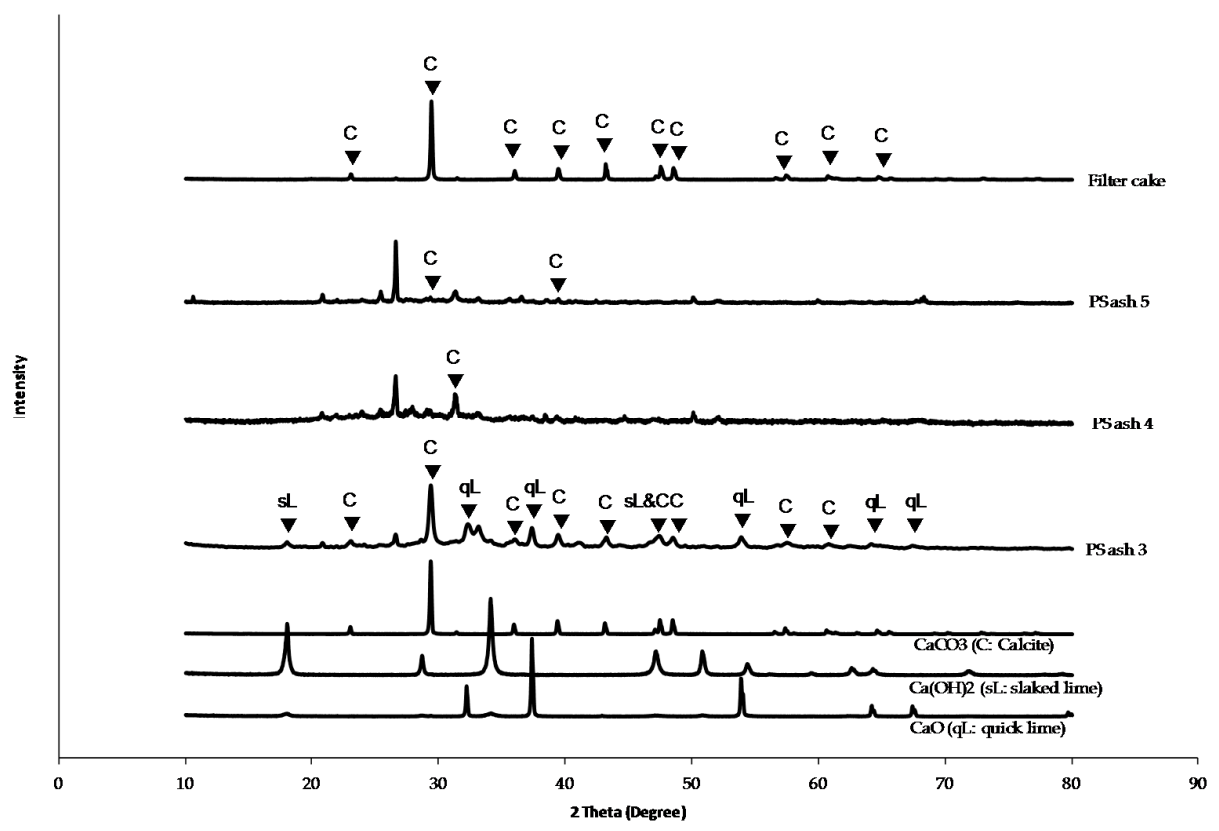

Figure 4. XRD Patterns of several calcium compounds and additives.

Figure 4 shows the X-ray diffraction patterns of several calcium compounds and additives. All of the peaks in the additives were compared with the peaks in each calcium compound. The results showed that PS Ash 3 contained $\mathrm{CaCO}_{3}, \mathrm{CaO}$, and $\mathrm{Ca}(\mathrm{OH})_{2} ;$ PS Ash 4 and PS Ash 5 contained small amounts of $\mathrm{CaCO}_{3}$, while FC contained the most amount of $\mathrm{CaCO}_{3}$. The XRD analysis results were consistent with the TG analysis results described above, and revealed that a relatively high content of $\mathrm{CaCO}_{3}$ in the FC caused this additive to yield low amounts of leached $\mathrm{Ca}$ ions and produce a relatively low value of $\mathrm{pH}$ mixture leachates, which was considered to be due to $\mathrm{CaCO}_{3}$ being an insoluble substance in pure water. Therefore, the contents of $\mathrm{CaO}$ and $\mathrm{Ca}(\mathrm{OH})_{2}$ (as water soluble $\mathrm{Ca}$ ) in PS Ash 3 caused this additive to yield high amounts of leached $\mathrm{Ca}$ ions and a higher value of $\mathrm{pH}$ mixture leachate than that of PS Ash 4, PS Ash 5, and FC. Regarding the higher amounts of leached Ca ions in PS Ash 5 than in PS Ash 3 (Figure 2), this could be attributed to the relatively high content of $\mathrm{SO}_{3}$ (detected by XRF) as an acid compound in PS Ash 5 (see Table 2). This is consistent with the reported study by Killingley et al. [28], where the balance between the concentration of alkaline-earth element, $\mathrm{Ca}$, in the ashes, and the proportion of potentially acid generating $\mathrm{SO}_{3}$ influenced the initial $\mathrm{pH}$ and leached $\mathrm{Ca}$ ions of the ash-water system.

Table 2. Trace element leaching suppression effect of additives.

\begin{tabular}{ccccccccc}
\hline Sample & $\begin{array}{c}\text { Ca } \\
(\mathbf{w t} \%)\end{array}$ & $\begin{array}{c}\text { As leach. } \\
\text { conc. } \mathbf{1} \\
(\boldsymbol{\mu g} / \mathbf{L})\end{array}$ & $\begin{array}{c}\text { L.I.R }^{2} \\
\mathbf{( \% )}\end{array}$ & $\begin{array}{c}\text { B leach. } \\
\text { conc. } \\
(\mathbf{m g} / \mathbf{L})\end{array}$ & $\begin{array}{c}\text { L.I.R } \\
\mathbf{( \% )}\end{array}$ & $\begin{array}{c}\text { Se leach. } \\
\text { conc. } \\
(\boldsymbol{\mu g} / \mathbf{L})\end{array}$ & $\begin{array}{c}\text { L.I.R } \\
(\mathbf{\%})\end{array}$ & Final pH \\
\hline FA H (1s) & 1.46 & 48.66 & 0.0 & 5.39 & 0.0 & 86.39 & 0.0 & 10.38 \\
Ca(OH)2 & 5 & 1.26 & 97.4 & 0.10 & 98.1 & 7.15 & 91.7 & 12.86 \\
PS Ash 3 & 5 & 5.12 & 89.5 & 0.87 & 83.9 & 15.00 & 82.6 & 11.58 \\
PS Ash 4 & 5 & 27.71 & 43.1 & 2.83 & 47.5 & 26.04 & 69.9 & 10.46 \\
PS Ash 5 & 5 & 12.06 & 75.2 & 1.48 & 72.6 & 10.60 & 87.7 & 10.63 \\
FC & 5 & 57.75 & -18.7 & 5.55 & -3.0 & 36.04 & 58.3 & 9.66 \\
Ca(OH)2 & 10 & 0.00 & 100.0 & 0.10 & 98.2 & 6.16 & 92.9 & 12.98 \\
PS Ash 3 & 10 & 1.84 & 96.2 & 0.41 & 92.4 & 8.57 & 90.1 & 11.94 \\
PS Ash 4 & 10 & 5.66 & 88.4 & 2.96 & 45.1 & 5.54 & 93.6 & 10.62 \\
PS Ash 5 & 10 & 6.71 & 86.2 & 1.06 & 80.3 & 2.80 & 96.8 & 10.51 \\
FC & 10 & 65.29 & -34.2 & 5.34 & 1.0 & 19.19 & 77.8 & 9.23 \\
\hline
\end{tabular}




\subsection{Effect of Additives on Arsenic Leaching}

The presence of $\mathrm{Ca}$ in $\mathrm{CFA}, \mathrm{pH}$, and the sorption process are known to play important roles in the leaching behavior of arsenic. Arsenic reacts with calcium to form a new stable compound, which is slightly soluble in water $[11,29]$. As the additives contained high native-calcium that could enrich the calcium content in CFA, the leaching of arsenic into the environment was expected to be reduced.

Figure 5 a shows the arsenic leaching concentration for FAH alone, and for fly ash under five kinds of additives at a $5 \%$ and $10 \%$ Ca content. The arsenic leaching concentration of FAH is shown on the far left as a comparison standard in Table 2. As seen in Figure $5 \mathrm{a}, \mathrm{Ca}(\mathrm{OH})_{2}$ was very effective in suppressing arsenic leaching, and the leaching amount of FAH greatly reduced from $48.7 \mu \mathrm{g} / \mathrm{L}$ to $1.3 \mu \mathrm{g} / \mathrm{L}$ in the $5 \%$ Ca content sample. The leaching inhibition rate was $97.4 \%$ and $100 \%$ for the $5 \%$ and $10 \%$ Ca content samples, respectively. The value of the 'leaching inhibition rate' was defined as [(leaching concentration of element in FAH)-(leaching concentration of element in FAH-additives mixture)/(leaching concentration of element in FAH)]. Comparing PS Ash 3, 4 and 5, it was seen that the arsenic suppressing effect was high in the order of PS Ash $3>5>4$ for the $5 \%$ Ca content sample and PS Ash $3>4>5$ for the 10\% Ca content sample. In addition, the arsenic leaching concentration was reliably reduced in the Ca 10\% sample compared to that in the Ca $5 \%$ sample. A plausible reason to describe the dramatic reduction of arsenic leaching concentration could be due to the relatively high Ca ions $\left(\mathrm{Ca}^{2+}\right)$ in $\mathrm{Ca}(\mathrm{OH})_{2}$ and in the PS Ash mixture leachates that react with oxyanionic species of arsenic at an alkaline $\mathrm{pH}$, which can form precipitates as a new stable compound or trap the oxyanionic species of arsenic through the ettringite phase formed under alkaline conditions, leading to a decrease in the leaching concentration of arsenic from FAH. This is consistent with previous studies that have shown that under a high $\mathrm{Ca}$ condition and $\mathrm{pH}>11.5$ (alkaline leachate), the dominating species, $\mathrm{AsO}_{4}{ }^{3-}$, formed a precipitate with $\mathrm{Ca}$ as a less soluble compound or trapped the arsenic species by the ettringite phase which prevented the leaching of arsenic [11,13]. Figure 6a presents the plots of Ca ion concentration and arsenic leaching concentration in the mixture leachates. The arsenic leaching concentration tended to decrease as the $\mathrm{Ca}$ ion concentration increased.

As discussed previously, there was an increase in $\mathrm{pH}$ when Ca was abundant in the leachates; Figure 7a shows the relationship between the leachate $\mathrm{pH}$ and the arsenic leaching concentration for all samples. Since $\mathrm{Ca}(\mathrm{OH})_{2}$ is completely water-soluble $\mathrm{Ca}$, the $\mathrm{pH}$ of $\mathrm{Ca}(\mathrm{OH})_{2}$ was the highest, around 13 . Overall, the $\mathrm{pH}$ and arsenic leaching concentration showed a linear relationship, where the higher the $\mathrm{pH}$, the lower the arsenic leaching concentration, and arsenic leaching was suppressed as the $\mathrm{pH}$ of the leachate became 11.5 or higher. This agrees with the observation reported by Jiao et al. [11] and Wang et al. [13], who claimed that at a $\mathrm{pH}$ above $11, \mathrm{AsO}_{4}{ }^{3-}$ (as the dominating species) forms precipitates with $\mathrm{Ca}$, which provides a suppressing effect on the mobilization of arsenic. Figure $7 \mathrm{a}$ shows that arsenic leaching was suppressed in PS Ash 4 and 5 despite a pH lower than 11.5, therefore, it was considered that alkaline elements other than $\mathrm{Ca}$ also contribute to suppress arsenic leaching. Thus, the concentration of alkaline elements in the leachates (such as $\mathrm{Na}, \mathrm{K}$, and $\mathrm{Mg}$ ) were measured and the relationships between them and arsenic leaching concentrations were examined. Figure 8a shows the relationship between the $\mathrm{Na}$ ion concentration and the arsenic leaching concentration in the mixture leachates. As seen in Figure 8a, the Na ion concentration showed a corresponding correlation with the arsenic leaching concentration, where the arsenic leaching concentration tended to decrease as the $\mathrm{Na}$ ion concentration increased. For $\mathrm{K}$ and $\mathrm{Mg}$ (as shown in Figures A1a and A2a), neither of them were clearly related to the arsenic leaching concentration. This result shows the reason why PS Ash 4 and 5 can be understood to suppress arsenic leaching as an effect of $\mathrm{Na}$ ions. The reason why the $\mathrm{Na}$ ion concentration as an alkaline element other than $\mathrm{Ca}$ influences the arsenic leaching concentration has been insufficiently explored, but warrants further investigation to be able to estimate further mixture compositions of additives for the more effective suppression of arsenic leaching. 


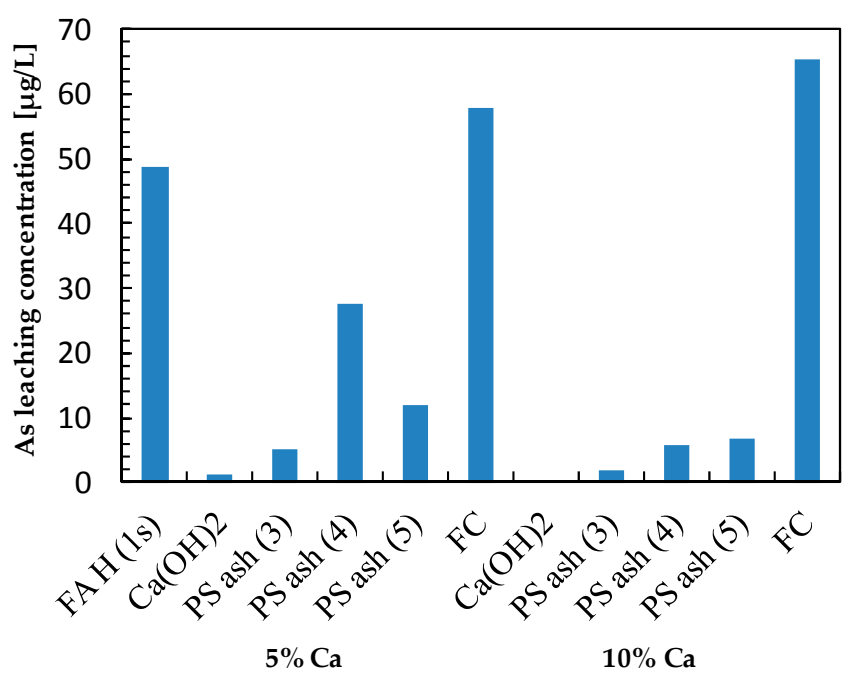

(a)

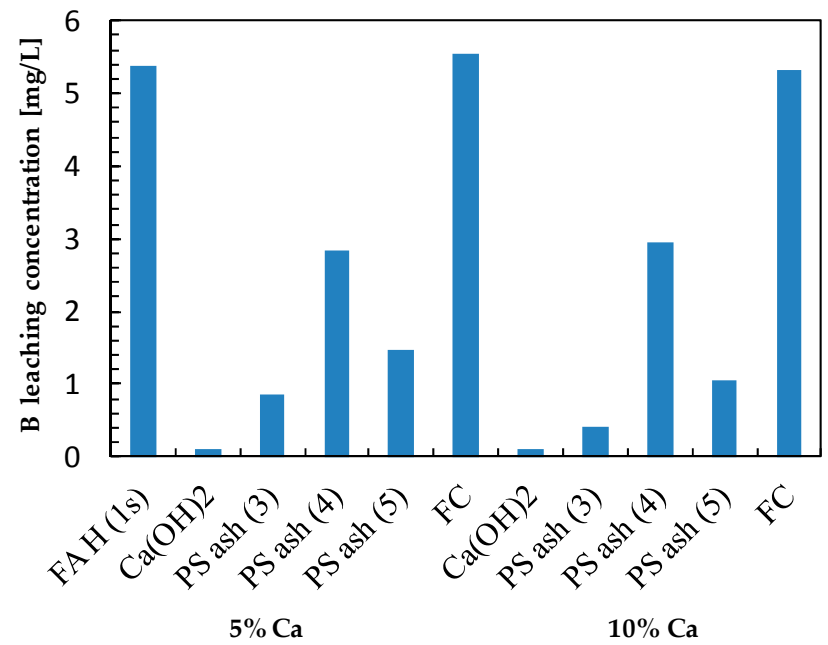

(b)

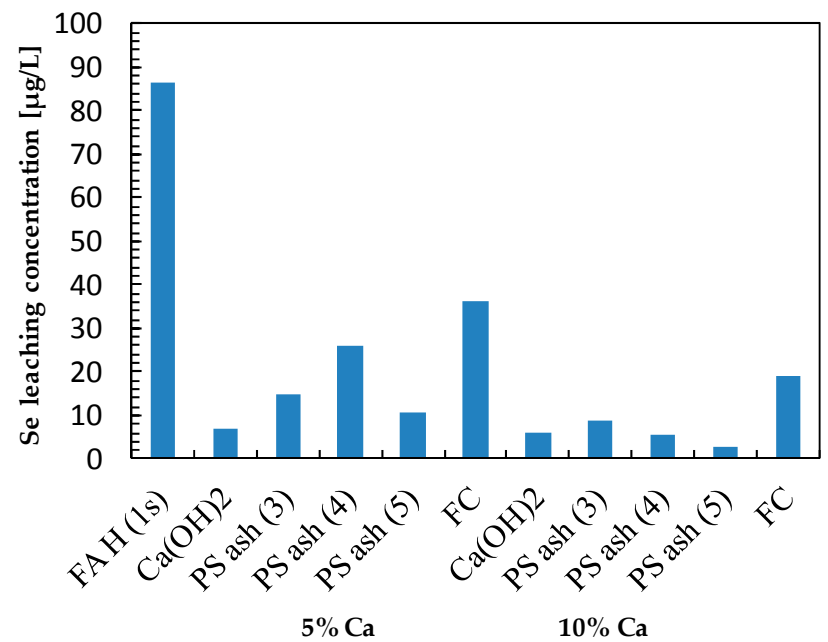

(c)

Figure 5. Trace element leaching concentration for fly ash $\mathrm{H}$ alone, and fly ash $\mathrm{H}$ under five kinds of additives addition for $5 \%$ and $10 \%$ Ca content samples: (a) arsenic; (b) boron; and (c) selenium. 


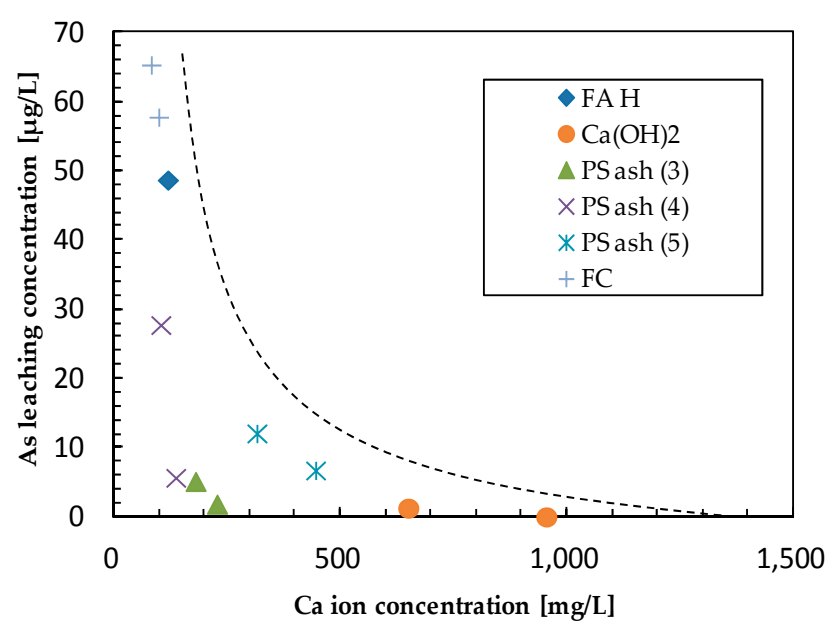

(a)

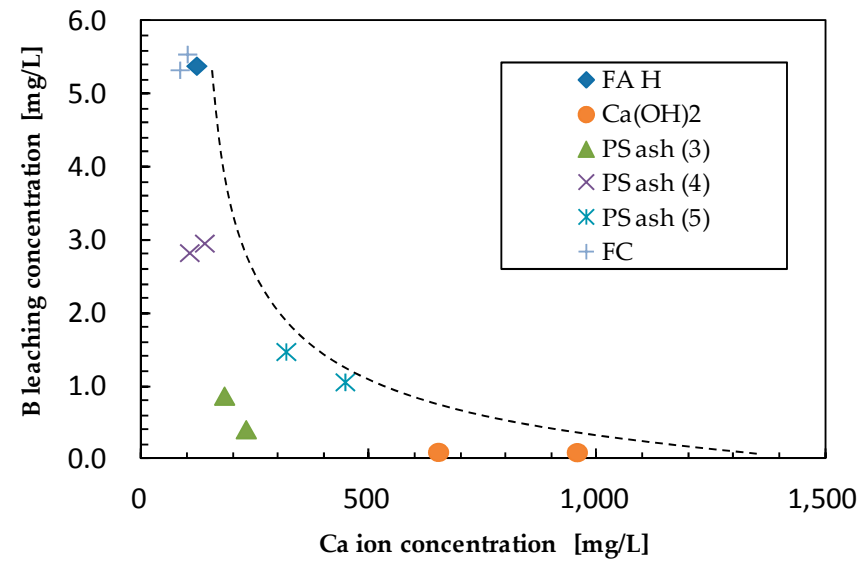

(b)

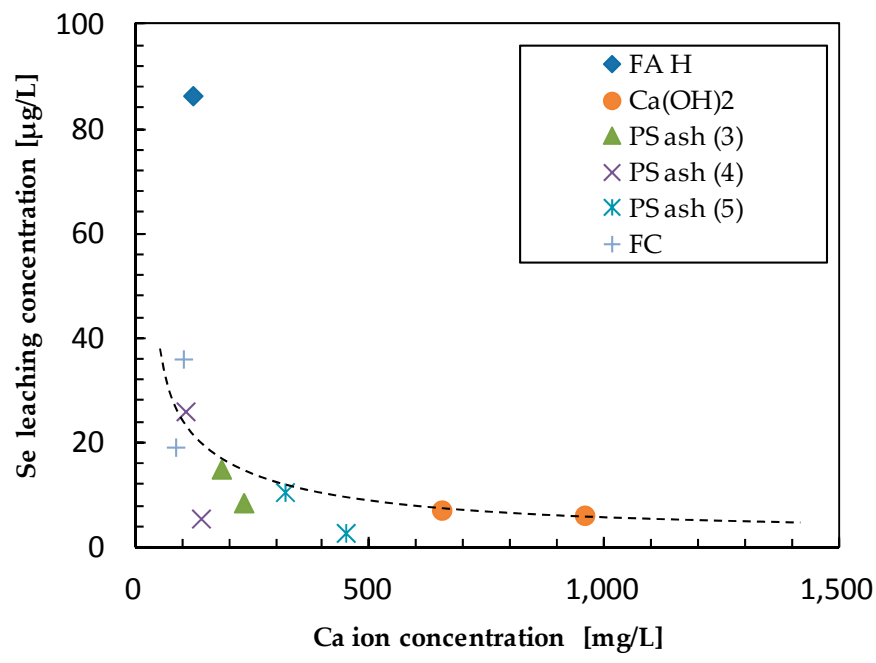

(c)

Figure 6. Relationship between the $\mathrm{Ca}$ ion leaching concentration and trace elements leaching concentration of five kinds of additives: (a) arsenic; (b) boron; and (c) selenium. 


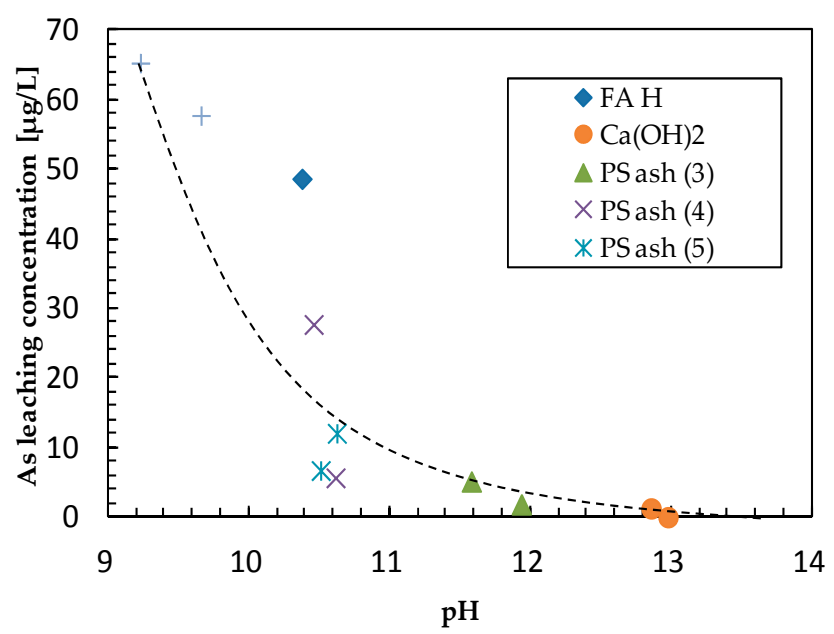

(a)

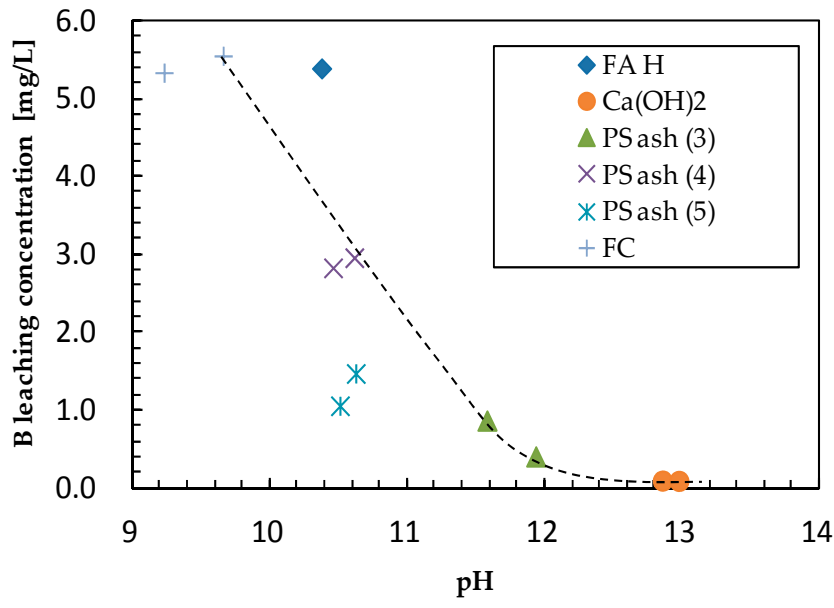

(b)

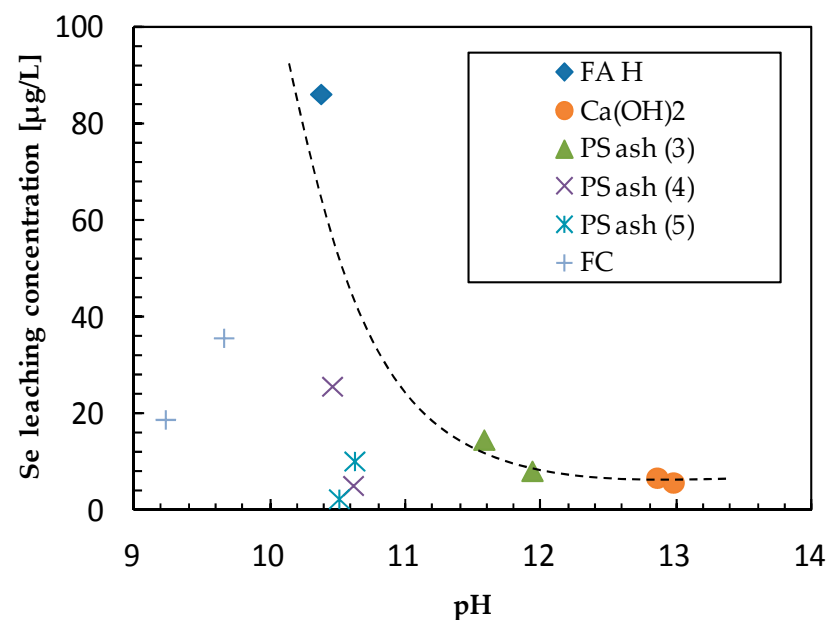

(c)

Figure 7. Relationship between the leachate $\mathrm{pH}$ and trace elements leaching concentration of five kinds of additives: (a) arsenic; (b) boron; and (c) selenium. 


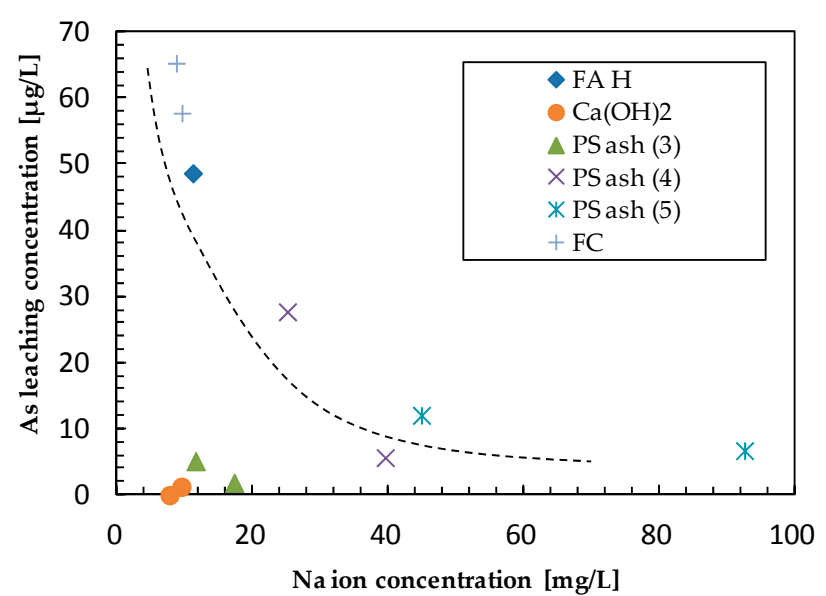

(a)

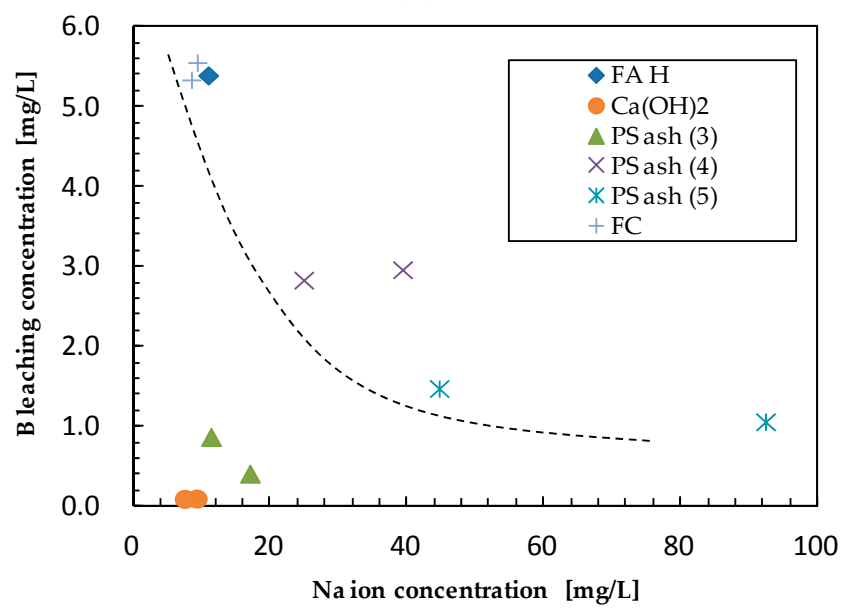

(b)

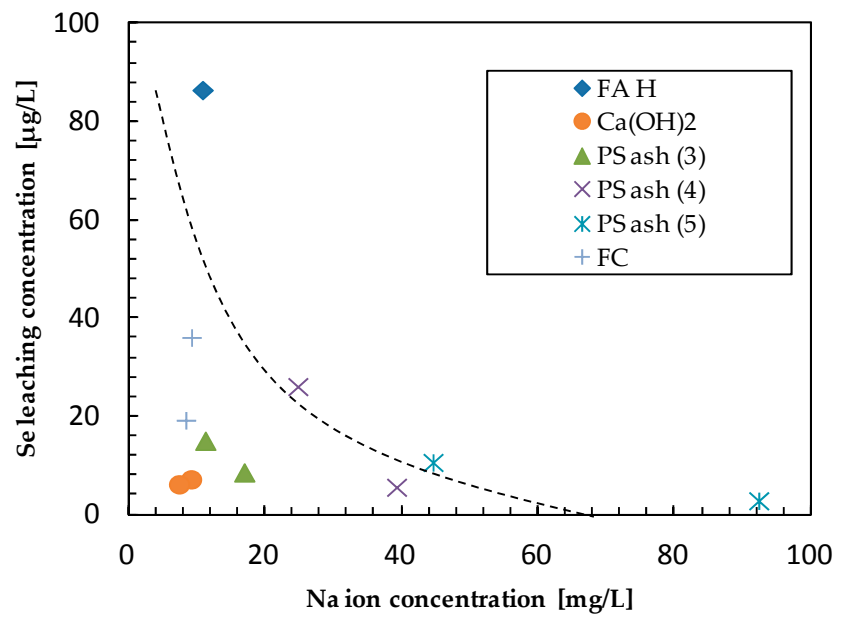

(c)

Figure 8. Relationship between the $\mathrm{Na}$ ion leaching concentration and trace elements leaching concentration of five kinds of additives: (a) arsenic; (b) boron; and (c) selenium.

For the arsenic leaching suppression effect on FC, despite the highest Ca content, FC was found to increase rather than decrease arsenic leaching. This could be explained by the relatively low $\mathrm{pH}$ of the FAH-FC mixture leachates of around 9.2-9.7, which is not an effective $\mathrm{pH}$ value for the suppression of arsenic leaching. Furthermore, the Ca ion concentration was $83-101 \mathrm{mg} / \mathrm{L}$, which is not an effective 
Ca ion concentration for the suppression of arsenic leaching due to the fact that the composition of FC is calcium carbonate based, which is a relatively stable substance.

\subsection{Effect of Additives on Boron Leaching}

Figure $5 \mathrm{~b}$ shows the boron leaching concentration for fly ash $\mathrm{H}$ (FAH) alone, and for fly ash under five kinds of additives at 5\% and 10\% Ca content (as shown in Table 2). As shown in Figure 5b, like arsenic leaching suppression, $\mathrm{Ca}(\mathrm{OH})_{2}$ was also very effective in suppressing boron leaching with a leaching inhibition rate of $98 \%$ for both $5 \%$ and $10 \%$ Ca content, respectively. This result indicated that As and $\mathrm{B}$ leaching can be simultaneously suppressed by the addition of $\mathrm{Ca}(\mathrm{OH})_{2}$. A comparison of PS Ash 3, 4, and 5, showed that the boron suppressing effect to be high in the order of PS Ash $3>5>4$ at both $5 \%$ and $10 \%$ Ca content samples. The dramatic reduction in the boron leaching concentration could be due to the relatively high level of $\mathrm{Ca}$ ions $\left(\mathrm{Ca}^{2+}\right)$ in $\mathrm{Ca}(\mathrm{OH})_{2}$ and in the PS ash mixture leachates that react with oxyanionic species of boron at an alkaline $\mathrm{pH}$, which can form new stable precipitates or trap the oxyanionic species of boron through the ettringite phase formed under alkaline conditions, leading to a decrease in the boron leaching concentration from FAH. This was consistent with a previous study that showed that with a high amount of $\mathrm{Ca}$ leaching and a $\mathrm{pH}>11$ (alkaline leachate), the dominating species—in this case, borate-formed a precipitate with Ca that was a less soluble compound or trapped the boron species in the ettringite phase and prevented the leaching of boron [12,30,31]. Figure $6 \mathrm{~b}$ presents the plots of the $\mathrm{Ca}$ ion concentration and boron leaching concentration in the mixture leachates. Like the arsenic results, the boron leaching concentration tended to decrease as the $\mathrm{Ca}$ ion concentration increased. Figure $7 \mathrm{~b}$ shows the relationship between the leachate $\mathrm{pH}$ and boron leaching concentration for all samples. Since the leaching test was performed simultaneously with As and Se, the $\mathrm{pH}$ data were the same data as As and Se (Table 2). As with arsenic, the $\mathrm{pH}$ and boron leaching concentration also showed a linear relationship; the higher the $\mathrm{pH}$, the lower the boron leaching concentration, and boron leaching was suppressed as the $\mathrm{pH}$ of the leachate became 11.5 or higher. This finding is consistent with Iwashita et al. [20], Hollis et al. [30], and Cetin et al. [31], who claimed that the B concentrations decreased with an increase in $\mathrm{pH}$ above 11, where large quantities of Ca minerals in the leachates may have caused the precipitation of $B$ with Ca. In the case of PS Ash 5, it seems that the boron leaching concentration was suppressed despite a $\mathrm{pH}$ lower than 11, and it was suggested that alkaline elements other than Ca could also contribute to the suppression of boron leaching. Therefore, the concentration of alkaline elements in the leachate (such as $\mathrm{Na}, \mathrm{K}$, and $\mathrm{Mg}$ ) were measured and the relationships between them and the boron leaching concentrations were examined. Figure $8 \mathrm{~b}$ shows the relation between the $\mathrm{Na}$ ion concentration and boron leaching concentration in the mixture leachates. As shown in Figure 8b, it appeared that the $\mathrm{Na}$ ion concentration showed a corresponding correlation to the boron leaching concentration; the boron leaching concentration tended to decrease as the $\mathrm{Na}$ ion concentration increased. For $\mathrm{K}$ and $\mathrm{Mg}$ (as shown in Figures A1b and A2b), neither of them was clearly related to the boron leaching concentration. This result demonstrates why PS Ash 5 could suppress boron leaching as an effect by $\mathrm{Na}$ ions. The reason why the $\mathrm{Na}$ ion concentration influences the boron leaching concentration has been insufficiently investigated, but it warrants further study in order to estimate the mixture composition of additives for the more effective suppression of boron leaching.

For a boron leaching suppression effect of FC like that observed with arsenic, FC did not have an inhibitory effect on boron leaching. Overall, the mechanism to suppress the leaching of arsenic and boron is similar. Figure 9 shows the relationship between the arsenic leaching concentration and the boron leaching concentration plotted for all samples. In general, they have a good correlation, indicating that As and B can be suppressed simultaneously. 


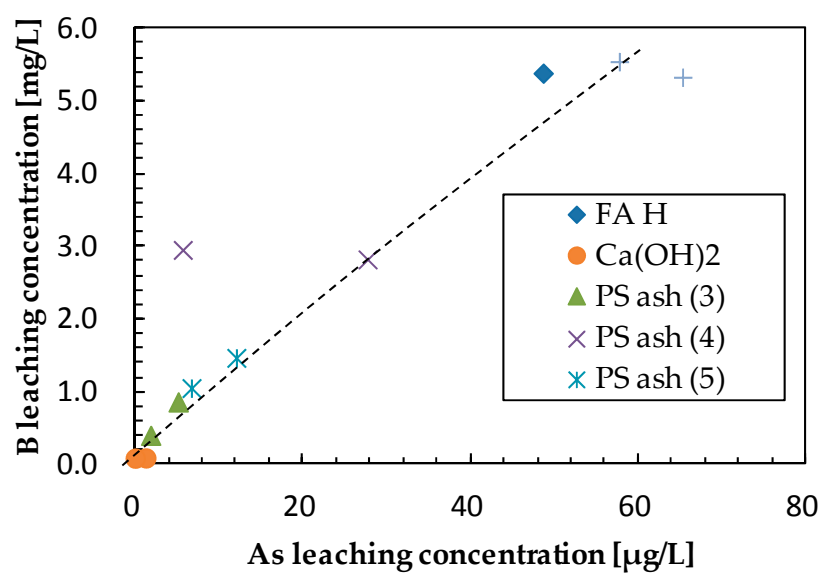

Figure 9. Relationship between the arsenic leaching concentration and the boron leaching concentration.

\subsection{Effect of Additives on Selenium Leaching}

Figure $5 \mathrm{c}$ shows the selenium leaching concentration for fly ash $\mathrm{H}(\mathrm{FAH})$ alone, and fly ash under five kinds of additives addition at $5 \%$ and $10 \%$ Ca content (Table 2). As shown in Figure $5 c, \mathrm{Ca}(\mathrm{OH})_{2}$ was also very effective in suppressing selenium leaching with a leaching inhibition rate of $91 \%$ for both $5 \%$ and $10 \%$ Ca contents, respectively. This result indicated that As, B, and Se leaching could be simultaneously suppressed by the addition of $\mathrm{Ca}(\mathrm{OH})_{2}$. A comparison of the leaching suppression effect by $\mathrm{Ca}(\mathrm{OH})_{2}$ for As, $\mathrm{B}$, and Se showed that the leaching inhibition rate when Ca content was $5 \%$ was $97.4 \%, 98.1 \%$, and $91.7 \%$, respectively. Therefore, the inhibitory effect of Ca was high in the order of B $>$ As $>$ Se. When comparing PS Ash 3, 4, and 5, it could be seen that the selenium suppression effect was increased in the order of PS Ash $5>3>4$ for the $5 \%$ Ca content sample, and PS Ash $5>4>3$ for the $10 \%$ Ca sample. In addition, it could be seen that the selenium leaching concentration was reliably reduced in the Ca 10\% sample compared to the Ca 5\% sample. The dramatic reduction of the selenium leaching concentration could be due to the relatively high level of $\mathrm{Ca}$ ions $\left(\mathrm{Ca}^{2+}\right)$ and $\mathrm{Ca}(\mathrm{OH})_{2}$ in the PS ash mixture leachates that react with oxyanionic species of selenium at an alkaline $\mathrm{pH}$, which formed precipitates as a new stable compound or trapped the oxyanionic species of selenium through the ettringite phase formed under alkaline conditions, thus leading to a decrease in the leaching concentration of selenium from FAH. This is consistent with the previous study that under high Ca conditions and a $\mathrm{pH}>11$ (alkaline leachate), the dominating species, $\mathrm{SeO}_{3}{ }^{2-}$, formed a precipitate with $\mathrm{Ca}$ as a less soluble compound or trapped the selenium species in the ettringite phase and prevented the leaching of selenium [13,32,33]. Figure $6 \mathrm{c}$ presents the plots of the Ca ion concentration and selenium leaching concentration in the mixture leachates. Like the results of arsenic and boron, the selenium leaching concentration tended to decrease as the Ca ion concentration increased.

Figure $7 \mathrm{c}$ shows the relationship between the leachate $\mathrm{pH}$ and the selenium leaching concentration for all samples. As with arsenic and boron, the $\mathrm{pH}$ and the selenium leaching concentration also showed a linear relationship; in general, the selenium leaching concentration decreased with increasing $\mathrm{pH}$, and selenium leaching was suppressed as the $\mathrm{pH}$ of the leachate became 11 or higher. This finding was consistent with Izquierdo et al. [21], Morar et al. [32], Jankowski et al. [33], and Solen-Tishmack et al. [34], who claimed that the Se concentrations decreased with an increase in $\mathrm{pH}$ above 11 due to the substitution of Se in the structure of ettringite. Figure $5 \mathrm{c}$ shows that selenium leaching was suppressed in PS Ash 4 and 5. Although the $\mathrm{pH}$ was lower than 11, it is thought that alkaline elements other than Ca also contributed to the suppression of selenium leaching. Therefore, the concentration of alkaline elements in the leachate (such as $\mathrm{Na}, \mathrm{K}$, and $\mathrm{Mg}$ ) were measured and the relationships between them and selenium leaching concentrations were examined. Figure 8c shows the relationship between the $\mathrm{Na}$ ion concentration and the selenium leaching concentration in the mixture leachates. As seen in Figure 8c, it seemed that the Na ion concentration showed a corresponding 
correlation to the selenium leaching concentration, where the selenium leaching concentration tended to decrease as the $\mathrm{Na}$ ion concentration increased. For $\mathrm{K}$ and $\mathrm{Mg}$ (as shown in Figures $\mathrm{A} 1 \mathrm{c}$ and A2c), neither of them were clearly related to the selenium leaching concentration. This result showed why PS Ash 4 and 5 could suppress selenium leaching as an effect of the $\mathrm{Na}$ ions. The reasons as to why the $\mathrm{Na}$ ion concentration is one of the alkaline elements other than $\mathrm{Ca}$ that influence the selenium leaching concentration has also been insufficiently considered, but is needs to be further understood in order to be able to estimate further mixture compositions of additives to more effectively suppress selenium leaching.

In contrast to arsenic and boron, FC showed some effect on selenium leaching suppression. The decrease in selenium leaching may have been due to the presence of $\mathrm{Al}_{2} \mathrm{O}_{3}$ and $\mathrm{Fe}_{2} \mathrm{O}_{3}$, as well as the $\mathrm{Ca}$ content and leached $\mathrm{Ca}$ ion content in $\mathrm{FC}$, as reported by previous observations where $\mathrm{Se}$ was controlled by sorption reactions that occurred on the surface of metal oxides such as $\mathrm{Al}_{2} \mathrm{O}_{3}$ and $\mathrm{Fe}_{2} \mathrm{O}_{3}[35,36]$. These oxides may provide additional surface area to which positively charged ions may attach, resulting in decreased Se concentration in aqueous solutions [37].

Figure 10 shows the relationship between the arsenic leaching concentration and selenium leaching concentration, and Figure 11 shows the relationship between the boron leaching concentration and selenium leaching concentration for all samples. In general, they had good correlation, indicating that As, B and Se could be suppressed at the same time.

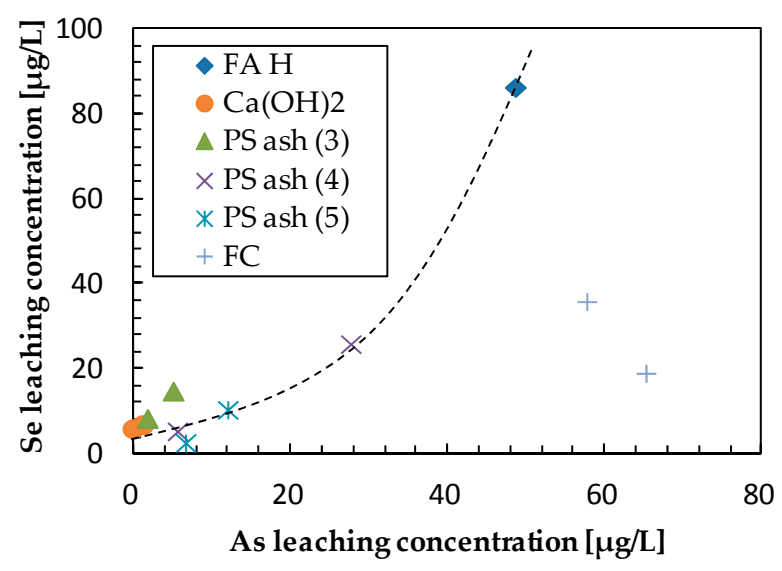

Figure 10. Relationship between the arsenic leaching concentration and the selenium leaching concentration.

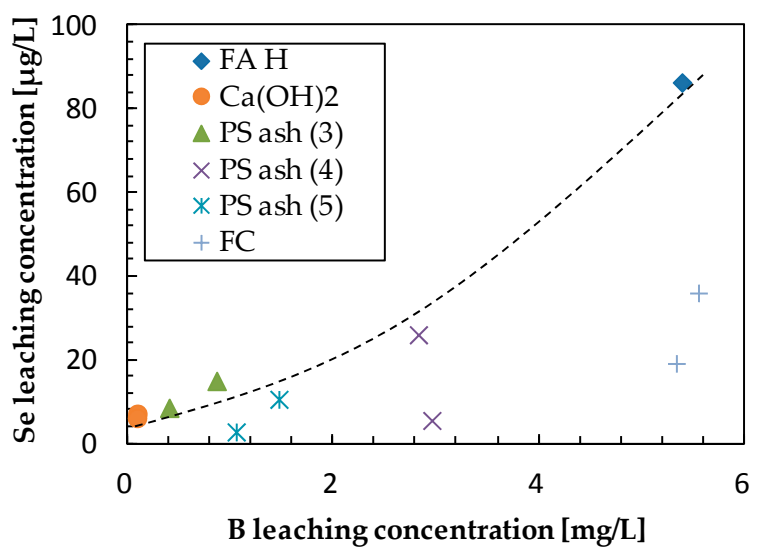

Figure 11. Relationship between the boron leaching concentration and the selenium leaching concentration. 


\subsection{Comprehensive Evaluation of Leaching Suppression Materials}

As shown above, PS Ash had the effect of simultaneously suppressing the leaching of As, B, and $\mathrm{Se}$, and it has become clear that it is very promising as a practical leaching suppression material. Although FC had some effect on Se leaching suppression, it did not work for As and B, and was found overall to be inappropriate as a leaching suppression material. Figure 12 plots the leaching inhibition rates of As, B, and Se by the PS Ash as radar charts for the Ca $5 \%$ and $10 \%$ samples. In these figures, it can be comprehensively evaluated that the one having the largest area had the effect of simultaneously suppressing As, B, Se. From this figure, PS Ash 3 was the most suitable material as a suppression material, followed by PS Ash 5 and PS Ash 4, respectively. For the three elements As, $\mathrm{B}$, Se, the only elution suppression material satisfying the soil environmental standard was PS Ash 3 , with a $\mathrm{Ca}=10 \%$ setting.

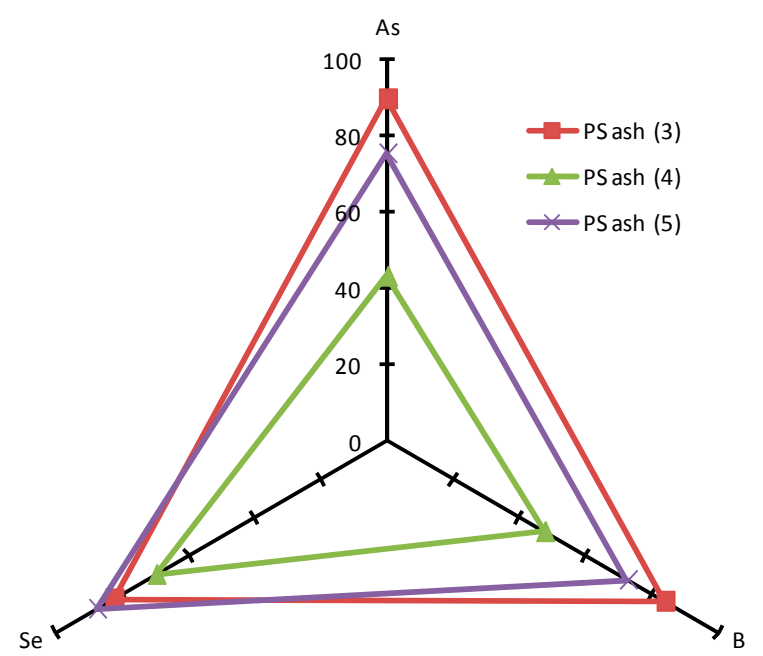

(a)

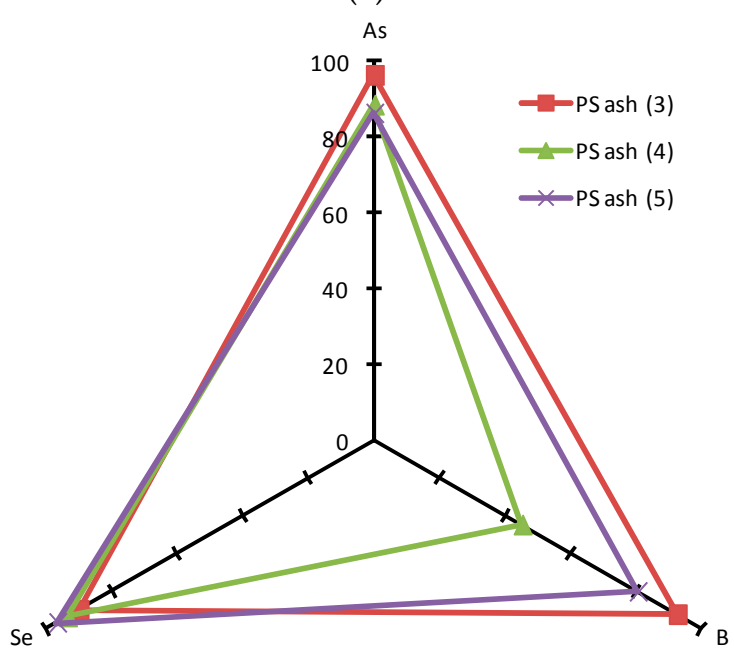

(b)

Figure 12. Trace elements (arsenic, boron, and selenium) leaching inhibition rate for (a) $5 \%$ Ca content; and (b) $10 \%$ Ca content samples.

\section{Conclusions}

This study investigated the effect of additives on the leaching characteristics of As, B, and Se in coal fly ash. We proposed $\mathrm{Ca}(\mathrm{OH})_{2}$, Paper Sludge Ash 3, Paper Sludge Ash 4, Paper Sludge Ash 5, and filter cake as new additives (suppression materials); adjusted the Ca concentration in the finished mixture 
to $5 \%$ and $10 \%$; and verified the simultaneous leaching suppressing effect of As, B, and Se. The results revealed that all additives (other than filter cake) showed a simultaneous leaching suppression effect. However, only the leaching suppression effect of PS Ash 3 satisfied the soil environmental standard with Ca concentration of $10 \%$. Other additives could meet the soil standards by increasing the $\mathrm{Ca}$ concentration to a higher level.

Acknowledgments: The financial support from Tohoku Electric Power Company is gratefully acknowledged. The authors would like to thank Hayakawa Yukio for his valuable contributions in improving the manuscript. The authors also thank Erda Rahmilaila Desfitri for her help in XRD analysis. Sincere thanks to the editor and reviewers for their detailed reviews that led to substantial improvements in this paper.

Author Contributions: Akihiro Takeyama and Shinji Kambara conceived and designed the experiments; Akihiro Takeyama, Farrah Fadhillah Hanum and Sri Hartuti performed the experiments; Akihiro Takeyama and Sri Hartuti analyzed the data; Shinji Kambara contributed reagents, materials, analysis tools; Sri Hartuti and Akihiro Takeyama wrote the paper.

Conflicts of Interest: The authors declare no conflict of interest.

\section{Appendix A}

To obtain the Ca content of the finished mixture at $5 \%$ or $10 \%$, the amount of each additive and FAH mixed was calculated based on the $\mathrm{CaO}$ concentration in the ash (Table 1). For example, when preparing a Ca $5 \%$ sample with FAH ( $x$ gram) and PS Ash 3 ( $y$ gram) based on $100 \mathrm{~g}$ of the finished mixture, considering the molecular weight of $\mathrm{CaO} 56.078$ and the molecular weight of $\mathrm{Ca} 40.078$, $x+y=100,2.05(40.078 / 56.078) x+46.31(40.078 / 56.078) y=5$, from the simultaneous equations, the amount of $x$ becomes $88.78 \mathrm{~g}$ and that of $y$ becomes $11.22 \mathrm{~g}$.

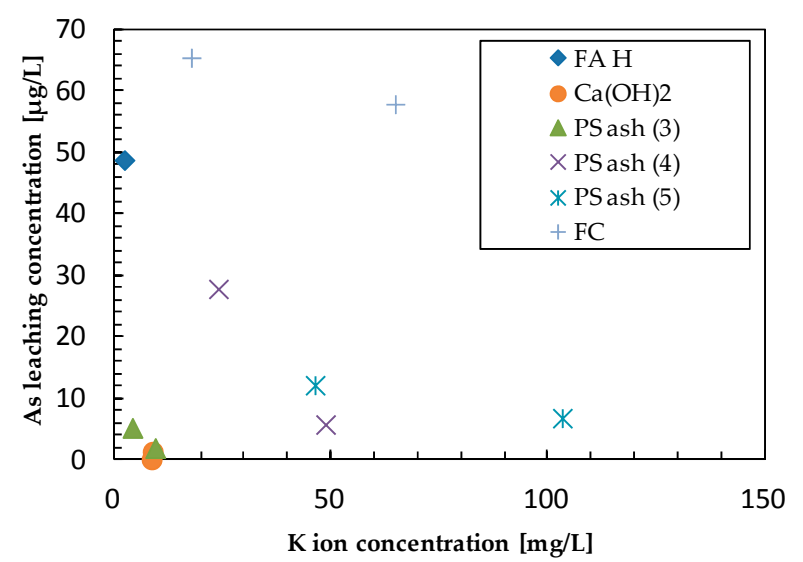

(a)

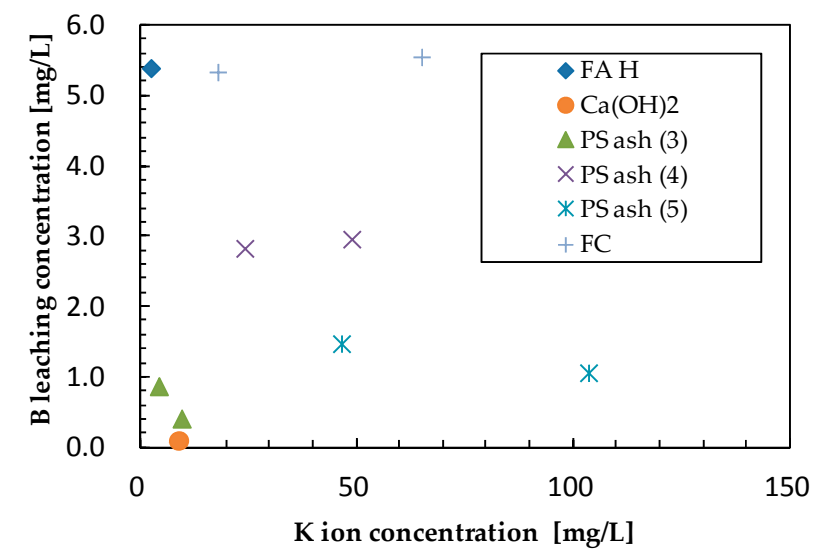

(b)

Figure A1. Cont. 


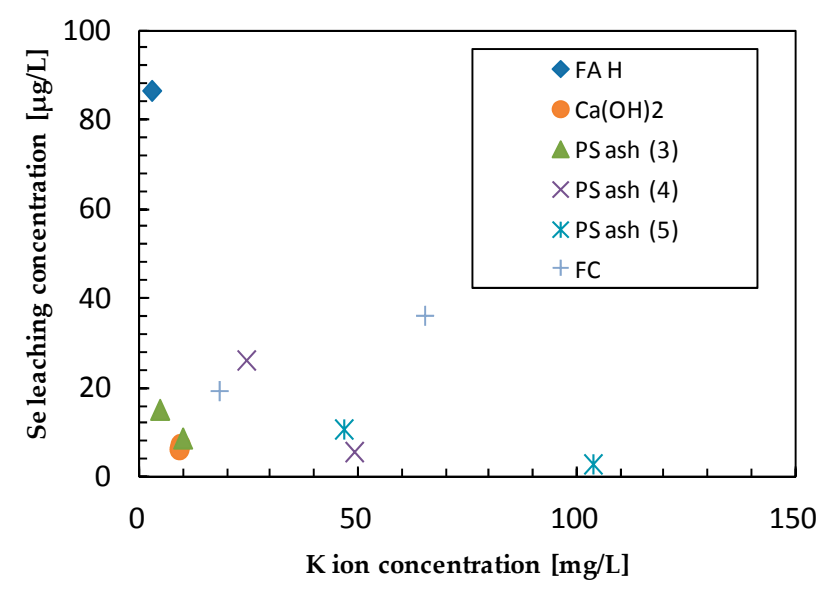

(c)

Figure A1. Relationship between the $\mathrm{K}$ ion leaching concentration and trace elements leaching concentration of five kinds of additives: (a) arsenic; (b) boron; and (c) selenium.

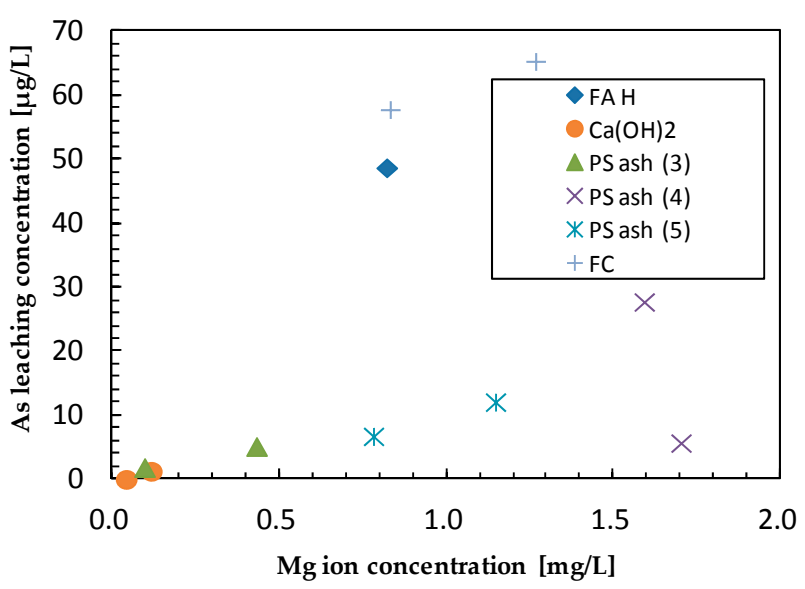

(a)

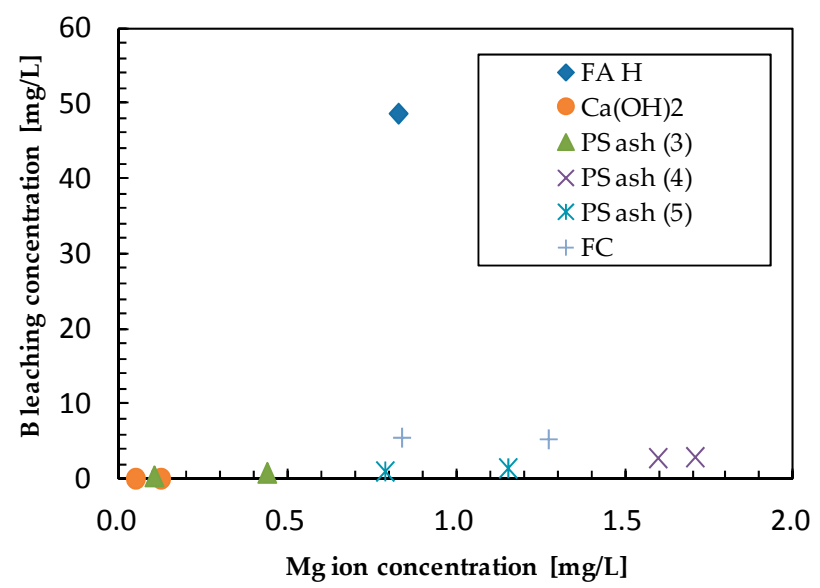

(b)

Figure A2. Cont. 


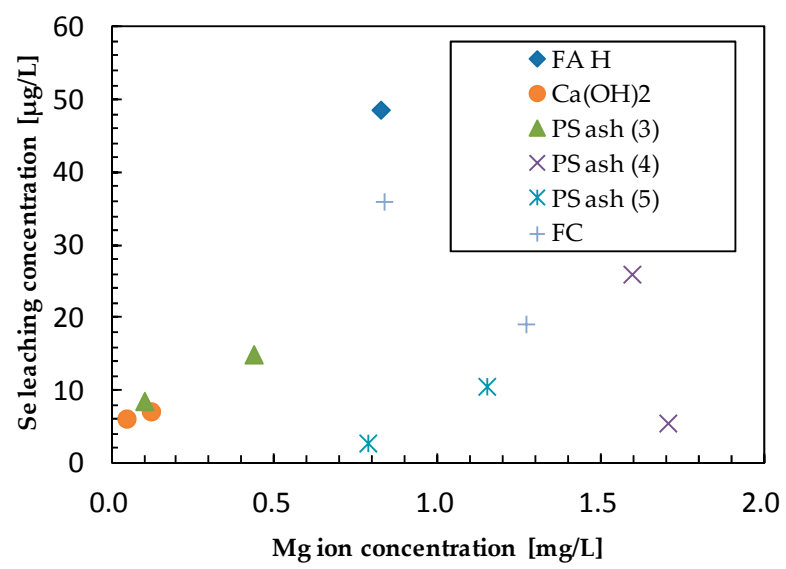

(c)

Figure A2. Relationship between the $\mathrm{Mg}$ ion leaching concentration and trace elements leaching concentration of five kinds of additives: (a) arsenic; (b) boron; and (c) selenium.

\section{References}

1. Merrick, D. Trace Elements from Coal Combustion: Emission; IEA Coal Research: London, UK, 1987.

2. World-Wide Coal Combustion Products Network (WWCCPN). Available online: http:/ /www.wwccpn.org/ (accessed on 31 March 2017).

3. Jones, D.R. The Leaching of Major and Trace Elements from Coal Ash. In Environmental Aspects of Trace Elements in Coal; Swaine, D.J., Goodarzi, F., Eds.; Kluwer Academic Publishers: Dordrecht, The Netherlands, 1995; Volume 228, pp. 221-262.

4. Baykal, G.; Edincliler, A.; Saygili, A. Highway embankment construction using fly ash in cold regions. Resour. Conversat. Recycl. 2004, 42, 209-222. [CrossRef]

5. Edil, T.B.; Acosta, H.A.; Benson, C.H. Stabilizing soft fine-grained soils with fly ash. J. Mater. Civ. Eng. ASCE 2006, 18, 283-294. [CrossRef]

6. Tastan, E.O.; Edil, T.B.; Benson, C.H.; Aydilek, A.H. Stabilization of organic soils with fly ash. J. Geotech. Geoenviron. Eng. ASCE 2011, 137-139, 819-833. [CrossRef]

7. Bargagli, R. The elemental composition of vegetation and the possible incidence of soil contamination of samples. Sci. Total Environ. 1995, 176, 121-128. [CrossRef]

8. Kondo, H.; Ishiguro, Y.; Ohno, K.; Nagase, M.; Toba, M.; Takagi, M. Naturally occurring arsenic in the groundwaters in the southern region of Fukuoka prefecture, Japan. Water Res. 1999, 33, 1967-1972. [CrossRef]

9. Wegman, D.H.; Eisen, E.A.; Hu, X.; Woskie, S.R.; Smith, R.G.; Garabrant, D.H. Acute and chronic respiratory effects of sodium borate particulate exposures. Environ. Health Perspect. 1994, 102, 119-128. [CrossRef] [PubMed]

10. U.S. Environmental Protection Agency (U.S. EPA). EPA's Report on the Environment (Roe); U.S. EPA: Washington, DC, USA, 2008; EPA/600/R-07/045F (NTIS PB2008-112484).

11. Jiao, F.; Ninomiya, Y.; Zhang, L.; Yamada, N.; Sato, A.; Dong, Z. Effect of coal blending on the leaching characteristics of arsenic in fly ash from fluidized bed coal combustion. Fuel Process. Technol. 2012, 106, 769-775. [CrossRef]

12. Iwashita, A.; Sakaguchi, Y.; Nakajima, T.; Takanashi, H.; Ohki, A.; Kambara, S. Leaching characteristics of boron and selenium for various coal fly ashes. Fuel 2005, 84, 479-485. [CrossRef]

13. Wang, T.; Wang, J.; Tang, Y.; Shi, H.; Ladwig, K. Leaching characteristics of arsenic and selenium from coal fly ash: Role of Calcium. Energy Fuel 2009, 23, 2959-2966. [CrossRef]

14. Van der Hoek, E.E.; Bonouvrie, P.A.; Comans, R.N.J. Sorption of As and Se on mineral components of fly ash: Relevance for leaching processes. Appl. Geochem. 1994, 9, 403-412. [CrossRef]

15. Van der Hoek, E.E.; Commans, R.N.J. Modelling As and Se leaching from acidic fly ash by sorption on iron (hydr) oxide in the fly ash matrix. Eniron. Sci. Technol. 1996, 30, 517-523. [CrossRef]

16. Hartuti, S.; Kambara, S.; Takeyama, A.; Hanum, F.F. Leaching Characteristic of Arsenic in Coal Fly Ash. J. Mater. Sci. Eng. B 2017, 7, 19-26. [CrossRef] 
17. Bothe, J.V., Jr.; Brown, P.W. Arsenic Immobilization by Calcium Arsenate formation. Environ. Sci. Technol. 1999, 33, 3806. [CrossRef]

18. Parks, J.L.; Novak, J.; MacPhee, M.; Itle, C.; Edwards, M. Effect of Ca on As release from ferric and alum residuals. J. Am. Water Works Assoc. 2003, 95, 108-118.

19. Warren, C.J.; Dudas, M.J. Leaching behavior of selected trace elements in chemically weathered alkaline fly ash. Sci. Total Environ. 1988, 76, 229-246. [CrossRef]

20. Gitari, W.M.; Fatoba, O.O.; Petrik, L.F.; Vadapalli, W.R.K. Leaching characteristics of selected South African fly ashes: Effect of $\mathrm{pH}$ on the release of major and trace species. J. Environ. Sci. Health Part A 2009, 44, 206-220. [CrossRef] [PubMed]

21. Quina, M.J.; Bordado, J.C.M.; Quinto-Ferreira, R.M. The influence of $\mathrm{pH}$ on the leaching behavior of inorganic components from municipal solid waste APC residues. Waste Manag. 2010, 29, 2483-2493. [CrossRef] [PubMed]

22. Jankowski, J.; Colin, R.W.; French, D.; Groves, S. Mobility of trace elements from selected Australian fly ashes and its potential impact on aquatic ecosystems. Fuel 2006, 85, 243-256. [CrossRef]

23. Mudd, G.M.; Weaver, T.R.; Kodikara, J. Environmental geochemistry of leachate from leached brown coal ash. J. Environ. Eng. 2004, 130, 1514-1526. [CrossRef]

24. Johnson, C.A.; Kaeppeli, M.; Brandenberger, S.; Ulrich, A.; Bauman, W. Hydrological and geochemical factors affecting leachate composition in municipal solid waste incinerator bottom ash. Part II. The geochemistry of leachate from Landfill Lostorf, Switzerland. J. Contam. Hydrol. 1999, 40, 239-259. [CrossRef]

25. Kato, M.; Hari, T.; Saito, S.; Shibukawa, M. Determination of free lime in steelmaking slags by use of ethylene glycol extraction/ICP-AES and thermogravimetry. Tetsu-to-Hagane 2014, 100, 340-345. [CrossRef]

26. Zelic, J.; Rusic, D.; Krstulovic, R. Kinetic analysis of thermal decomposition of $\mathrm{Ca}(\mathrm{OH})_{2}$ formed during hydration of commercial Portland cement by DSC. J. Therm. Anal. Cal. 2002, 67, 613-622.

27. Lu, H.; Khan, A.; Smirniotis, P.G. Relationship between structural properties and $\mathrm{CO}_{2}$ capture performance of CaO-based sorbents obtained from different organometallic precursors. Ind. Eng. Chem. Res. 2008, 47, 6216-6220. [CrossRef]

28. Killingley, J.; McEvoy, S.; Dokumcu, C.; Stauber, J.; Dale, L. Trace Element Leaching from Fly Ash from Australian Power Stations. End of Grant Report, Australian Coal Association Research Program, Project C8051, CSIRO Division of Energy Technology; Cooperative Research Centre for Black Coal Utilisation: Newcastle, Australia, 2000; p. 98.

29. Elseewi, A.A.; Page, A.L.; Grimm, S.R. Chemical characterization of fly ash aqueous systems. J. Environ. Qual. 1980, 9, 424-428. [CrossRef]

30. Hollis, J.F.; Keren, R.; Gal, M. Boron release and sorption by fly ash as affected by pH and particle sizes. J. Environ. Qual. 1988, 17, 181-185. [CrossRef]

31. Cetin, B.; Aydilek, A.H. pH and fly ash type effect on trace metal leaching from embankment soils. Resour. Conserv. Recycl. 2013, 80, 107-117. [CrossRef]

32. Izquierdo, M.; Koukouzas, N.; Touliou, S.; Panopoulos, K.; Querol, X.; Itskos, G. Geochemical controls on leaching of lignite-fired combustion by-products from Greece. Appl. Geochem. 2011, 26, 1599-1606. [CrossRef]

33. Morar, D.; Aydilek, A.H.; Seagren, E.A.; Demirkan, M.M. Metal leaching from fly ash-sand reactive barriers. J. Environ. Eng. ASCE 2012, 138, 815-825. [CrossRef]

34. Solen-Tishmack, J.K.; McCarthy, G.J.; Docktor, B.; Eylands, K.E.; Thompson, J.S.; Hassett, D.J. High-calcium coal combustion by-products: Engineering properties, ettringite formation, and potential application in solidification and stabilization of selenium and boron. Cem. Concr. Res. 1995, 25, 658-670. [CrossRef]

35. Cervera, M.L.; Arnal, M.C.; de la Guardia, M. Removal of heavy metals by using adsorption on alumina or chitosan. Anal. Bioanal. Chem. 2003, 375, 820-825.

36. Su, T.; Guan, X.H.; Gu, G.W.; Wang, J.M. Adsorption characteristics of As(V), Se(IV) and V(V) onto activated alumina: Effects of pH, surface loading, and ionic strength. J. Colloid Interface Sci. 2008, 326, 347-353. [CrossRef] [PubMed]

37. Cornell, R.M.; Schwertmann, U. The Iron Oxides: Structure, Properties, Reactions, Occurrences and Uses, 2nd ed.; Wiley-VCH: Weinheim, Germany, 2003.

(C) 2017 by the authors. Licensee MDPI, Basel, Switzerland. This article is an open access article distributed under the terms and conditions of the Creative Commons Attribution (CC BY) license (http://creativecommons.org/licenses/by/4.0/). 